\title{
FOOD IMPORTS AND FOOD SECURITY OF MAIN GLOBAL MARKET PLAYERS
}

\author{
Magdalena Jaworska, $\mathrm{PhD}^{1}$ \\ Faculty of Economics and Social Sciences, Poznań University of Life Sciences
}

\begin{abstract}
The main purpose of this paper was to assess the openness of trade in food products in the context of changes in food security levels. The period covered by this study is 1995-2015. The research was based on outcomes reported by main players of the global market. The basic source of data were online databases and reports. Once collected, the data was analysed with the use of quantitative and qualitative research methods. Selected statistical methods, indices of structure and dynamics, indicators of economic openness and indicators related to three dimensions of security (availability, access and stability) were used. The analysis resulted in numerous conclusions. In the study period, food imports followed a global growth trend with alternating periods of contrasting developments. In the countries covered by this study, the openness of trade in food was higher than that of global imports and followed a growth trend. The singularities of the development of the agri-food sector were reflected in decreasing values of the exports-to-imports ratio, and were decisive for the positive growth rate of per capita agri-food output. According to the analysis of relationships between changes in trade levels and selected food security indicators, imports proved to be positively correlated with physical and economic availability, and negatively correlated with stability. Based on the results, a general conclusion may be drawn that economic growth resulted in structural changes which contributed to improving access to food.
\end{abstract}

Keywords: food, food security, importers, international trade

JEL codes: F14, F41, Q17, F62

\section{INTRODUCTION}

Agriculture is subject to specific environmental, climate, production and socio-cultural conditions which complicate the situation in the agri-food market in a number of ways. On the one hand, the economic singularities of resources used in the production process result in a relatively low efficiency of agri-food manufacturing and processing. On the other hand, these products are considered to be a 'sensitive' commodity which is of key importance in the context of the need to ensure food security. Their critical importance in both economic and political terms is compounded by the fact that all countries around the world participate in agri-food trade, and that international trade itself continues to be the overarching dimension of progressing economic globalization. The above is the starting point for the investigation and questions on global food trade: how did the trade activity and food security level of key global market players evolve? Do these categories follow a parallel evolution or are they independent from each other? This is why the main purpose of this paper was to assess the openness of trade in food products with refer-

${ }^{1}$ Corresponding author: Wojska Polskiego 28,60-637 Poznań, Poland, jaworska@up.poznan.pl, +4861 8487134 
ence to changes in food security levels. Contributing to that objective were the analyses related to: a comparative assessment of the importance of food trade; the intensity of involvement of selected countries in the world food trade; an evaluation of food security levels in three dimensions; and a test of relationships between imports and food security.

\section{THEORETICAL BACKGROUND}

This paper is a part of the discussion on interactions between trade and food security. This topic is addressed at both a national and international level, including multilateral WTO trade negotiations. The extent of the negotiations, and especially the difficulties in developing a global framework to ensure consistency between national objectives and the reduction of food insecurity at a global level, emphasize the specific context of relationships between trade and food security (Krivonos, Morrison and Canigiani, 2015). According to the definition, food security exists when all people, at all times, have physical, social and economic access to sufficient, safe and nutritious food meeting dietary needs and food preferences necessary for an active and healthy life (FAO, 2017). The multidimensional nature of food security accentuates four fundamental pillars: availability, access, utilization and stability (UNCTAD, 2017a). Note that availability refers to the physical supply of food from all possible sources, e.g. all forms of domestic production, commercial imports, food aid, etc. (Aurino, 2014).

The activity of different countries in the global market for agri-food products is a consequence of real conditions of farming which impose limitations on output growth. The prevailing conditions are decisive for the spatial distribution, level and commodity structure of the supply of agricultural products and, as a consequence, for the need to meet the demand through imports (Herrmann, 2009). Meanwhile, by increasing the transnational interconnectedness between markets, globalization enables balancing local production instabilities (UNCTAD, 2017b) which means addressing demand in a relatively stable and fast way. However, it can also make a country increasingly dependent on food imports. Zhu drew at- tention to this fact when analysing the theoretical and empirical interactions between international trade and food security in China, and concluded that an increasing dependence on food imports will adversely affect food security. He also emphasized that while international trade is not necessarily the cause of food insecurity, it affects the demand for and supply of food production in the global market. Therefore, it also has an impact on prices, the increase of which aggravates a populations' income situation (Zhu, 2016).

Also, trade openness improves each dimension of food security. The flows from surplus to deficit areas improve the availability of food and increase the income of exporters (who charge higher prices in the market than would be possible without trade) and importers (who make purchases at lower prices) (Wacziarg and Welch, 2008). Trade may improve balanced nutrition patterns through product diversification while helping to make availability more stable as domestic production uncertainty is higher than the total production risk across international markets (Brooks and Matthews, 2015). International trade is also believed to have an important role in reducing the adverse effects of climate change on food security (Nelson, McCarl and Thayer, 2010; Chen et al., 2017). The observations conducted by FAO (2005) also confirm the existence of a positive relationship between market openness and food security. Therefore, the hypothesis may be formulated that efforts made to improve the food situation increase engagement in international trade, and therefore make up shortfalls in food production.

In this context, Yu and You (2013) paid attention to the developments which have taken place in the last two decades. A rapid growth of food prices in 2005-2008 and the recent economic downturns were factors that undermined global efforts for security. Also, increasing food availability through imports is a short-term solution. Many food importers either continue to struggle to fully address the domestic demand (Braun et al., 2008) or experience a clear deterioration of food availability. This can be caused by natural conditions (e.g. frequent floods or droughts) or human activity. Adverse developments are believed to be caused primarily by: high energy prices which entail a dramatic growth in the consumption of 
agricultural products used for the production of biofuels; a decline in agricultural productivity and international supply; climatic change which exposes food production to uncertainty; increased demand in international markets; and inefficient regulation of the futures market (Chatterjee and Murphy, 2013). The above shows that food security is highly vulnerable to threats involved in the global context of market processes.

\section{DATA AND METHODS}

This study covered food products identified as a product group in accordance with SITC (Standard International Trade Classification). The timeframe for this study is 1995-2015. Research was based on the outcomes of seven main players of the global market selected by average figures of trade flow. This group included the European Union, the United States, China, Japan, Canada, Korea, and Hong Kong (China). The basic source of data were online databases and reports, including those delivered by UNCTAD (the United Nations Conference on Trade and Development), FAO (the Food and Agriculture Organization), WTO (the World Trade Organization), OECD (the Organization for Economic Co-operation and Development) and WB (the World Bank). Once collected, the data was analysed with the use of both quantitative and qualitative research methods. To describe the structure of phenomena under consideration, selected statistical methods were used, including: measures of dependence (the Pearson correlation coefficient), measures of position, measures of volatility and structural and dynamic indicators. The analysis of the dynamics of the economic phenomena used the mid-term rate of changes, which enables evaluating the changes in the whole period covered by the study. It was calculated using the geometric mean. The comparative assessment of the importance of trade in food products, and of the intensity of involvement of selected countries in the world food trade was enabled by purposefully selected measures, such as: the trade openness rate $[$ import food/GDP $\times 100]$, the import rate $[\mathrm{import}$ food/GNI $\times 100]$, the import penetration index [import food / (GDP - import food + export food) $\times 100$ ], the import intensity index [import food/ production food $\times 100$ ], the share in total imports, and the internal comparative advantage measurement index (Trade Coverage).

Food security results may be analysed at multiple levels, from a global and national level of food availability, through the assessment of household access to food, to individual nutrition performance. For various reasons, it is difficult to reach a consensus on a common framework for food security monitoring on a national and global basis. This ultimately boils down to selecting the most adequate database for the assessment of the global level of food security (Aurino, 2014). Therefore, in this paper, progress in improving importer food security was assessed based on five indicators: value of agri-food production per capita; GDP per capita and the share of agri-food imports in total exports. The selection of indices was determined by the multidimensionality of food security and the macroeconomic nature of this analysis. The indices refer to three dimensions of security: availability, access and stability.

\section{RESULTS AND DISCUSSION}

Trade globalization has progressed despite crises, natural disasters or geopolitical tensions, which are also responsible for price instability and changes in the group of leading trading partners (WTO, 2015). Major events that affected the levels of international trade include: the Mexican peso crisis (1995-2001), the Asian financial crisis (1997), the adoption of the euro (2000), the bursting of the dot-com bubble (2001), the accession of China to the WTO (2001), the increase in oil prices resulting from a strong demand for natural resources in China, and the political instability in oil-producing countries. The last decade was determined by the consequences of the 2008 financial crisis caused by the collapse of the US subprime mortgage market, leading to a global recession in 2008-2011 (WTO, 2015). These external shocks have also left their imprint in the general trends of world trade flows in the agri-food sector. During the 21-year study period, agri-food trade volumes nearly tripled despite the declining importance of agriculture in the global economy considered in quantitative terms. In 1995, food imports accounted for 
USD 468,624 million (9.04\% of total imports) while in 2015 , they reached as much as USD $1,357,754$ $(8.23 \%)$. There were some contrasting fluctuations around the global growth trend. In these sub-periods, compared to global commodity trade trends, changes in agricultural trade volumes were less dynamic and relatively highly convergent (Jaworska, 2012).

The growth in global trade is accompanied by relatively insignificant changes in commodity structure (Aksoy, 2005); this affects imports more than exports and agricultural raw materials more than food. Nearly $40 \%$ of global demand originated from European Union countries, of which $2 / 3$ was addressed by internal trade. Other countries surveyed accounted for over $1 / 4$ of global food imports, and food trade did not represent a dominant share of their international trade. Moreover, the decreasing share of food imports in total imports was inductively confirmed to be a general pattern, except for Canada, the US and Korea. Of all the countries surveyed, only Canada and the US were not net food importers in 1995-2015 (Table 1). As regards other economies, the average import-to-export ratio ranged from 1.02 in China to 3.62 in Korea. The highest (though decreasing) ratio was recorded in Japan (18.34).

According to a comparative analysis of food trade transformation and intensity of involvement of global leaders, based on selected indicators of economic openness, a growth trend was observed in almost every country covered by this study (some exceptions were found mainly in China). In nominal terms, the annual average growth of global food imports was $5.46 \%$, and followed an upward trend in all countries considered. The highest growth rate was recorded in China (12.8\%) where the value of food purchased increased nearly twelve-fold from 1995 to 2015. In turn, the lowest level was observed in Japan which spent only $16 \%$ more on food in 2015 than 21 years prior.

High economic openness (measured as the import-to-GDP ratio) makes import-dependent countries exposed to external economic shocks, including threats posed by a sharp upward movement in prices in global markets. The openness of food trade was barely $1.63 \%$. In turn, the contribution of food to agricultural GDP was definitely higher, growing each year to reach nearly $44 \%$ in 2015 . However, it differed across importers covered by this study: the highest levels were reported in Hong Kong, the EU, Canada and Japan while China recorded the lowest rate, primarily because of internal conditions.

The penetration index, which informs of the proportion of domestic demand satisfied with imported products, is particularly important when assessing a country's involvement in international trade (Table 1). The rate of food demand covered by global food imports was $1.63 \%$ and grew steadily, especially in pre-recession years. Hong Kong and the EU saw

Table 1. Average annual growth rate of selected indices for main players of the global market in 1995-2015 (\%)

\begin{tabular}{|l|c|c|c|c|c|c|c|c|}
\hline Specification & World & EU28 & Canada & China & $\begin{array}{l}\text { Hong } \\
\text { Kong }\end{array}$ & Japan & Korea & USA \\
\hline Food imports & 5.46 & 4.30 & 6.69 & 12.80 & 4.45 & 0.76 & 6.52 & 6.70 \\
\hline Share of food imports & -0.47 & -0.35 & 1.80 & -0.67 & -0.88 & -2.33 & 0.45 & 1.00 \\
\hline Economy openness degree & 0.97 & 1.58 & 1.77 & -1.53 & 0.56 & 1.86 & 1.79 & 2.23 \\
\hline Imports ratio & 0.92 & 1.56 & 1.65 & -1.62 & 0.52 & 1.71 & 1.74 & 2.07 \\
\hline Import penetration & 0.97 & 1.58 & 1.76 & -1.57 & 0.49 & 1.84 & 1.76 & 2.22 \\
\hline Import intensity & 0.91 & 2.99 & 2.24 & 4.99 & 1.69 & 4.00 & 6.25 & 2.36 \\
\hline Food imports per capita & 4.15 & 4.05 & 5.61 & 12.13 & 3.59 & 0.69 & 5.93 & 5.72 \\
\hline
\end{tabular}

Source: calculations and author's own study based on: UNCTADstat (2018). International trade in goods and services, Economic trends (1995-2015) and FAOSTAT (2018). Food and agriculture data: Production. Population, Macro-Statistics, Food Security (1995-2015). 
a relatively high degree of dependence of their domestic demand on imports. The highest growth rate $(56 \%)$ was recorded in the US.

The assessment of activity of main global market players is supplemented with the analysis of import intensity of agricultural production. Globally, average contribution of food imports to final domestic food output in 1995-2014 was 47\%. Average absorption of imported agricultural commodities by production of economies under consideration was much higher, and followed an upward trend, particularly marked in Asian countries. Meanwhile, in China, the extent of food trade globalization was disproportionately low $(6.6 \%)$.

Analysis of per capita imports sheds some objective light on the assessment of importance and intensity of food trade at a level of global market leaders. In 1995-2015, the highest rates were recorded in Hong Kong, the EU, Canada and Japan, while the lowest were observed in the Chinese economy. Due to a relatively small population growth compared to commodity flow growth, imports per capita followed an upward trend, especially in China where annual growth rate was three times higher than in the world.

When considering availability and stabilization dimensions of food security at a national and global level, particular attention should be paid to two issues considered collectively: the ability to generate enough funds to finance required food imports; and domestic output per capita. Both for food and agricultural commodities, the average export-to-import ratio did not exceed $10 \%$ because of the relatively small importance of these products for total trading volume. The highest and the lowest exports-to-agricultural-imports ratios were recorded in Japan and China, respectively, while a general downward trend was evident (Fig. 1). Interestingly, the index doubled between 1995 and 2015 in countries other than net importers, i.e. Canada and the US. Similar changes were observed for the exports-to-food-imports ratio.

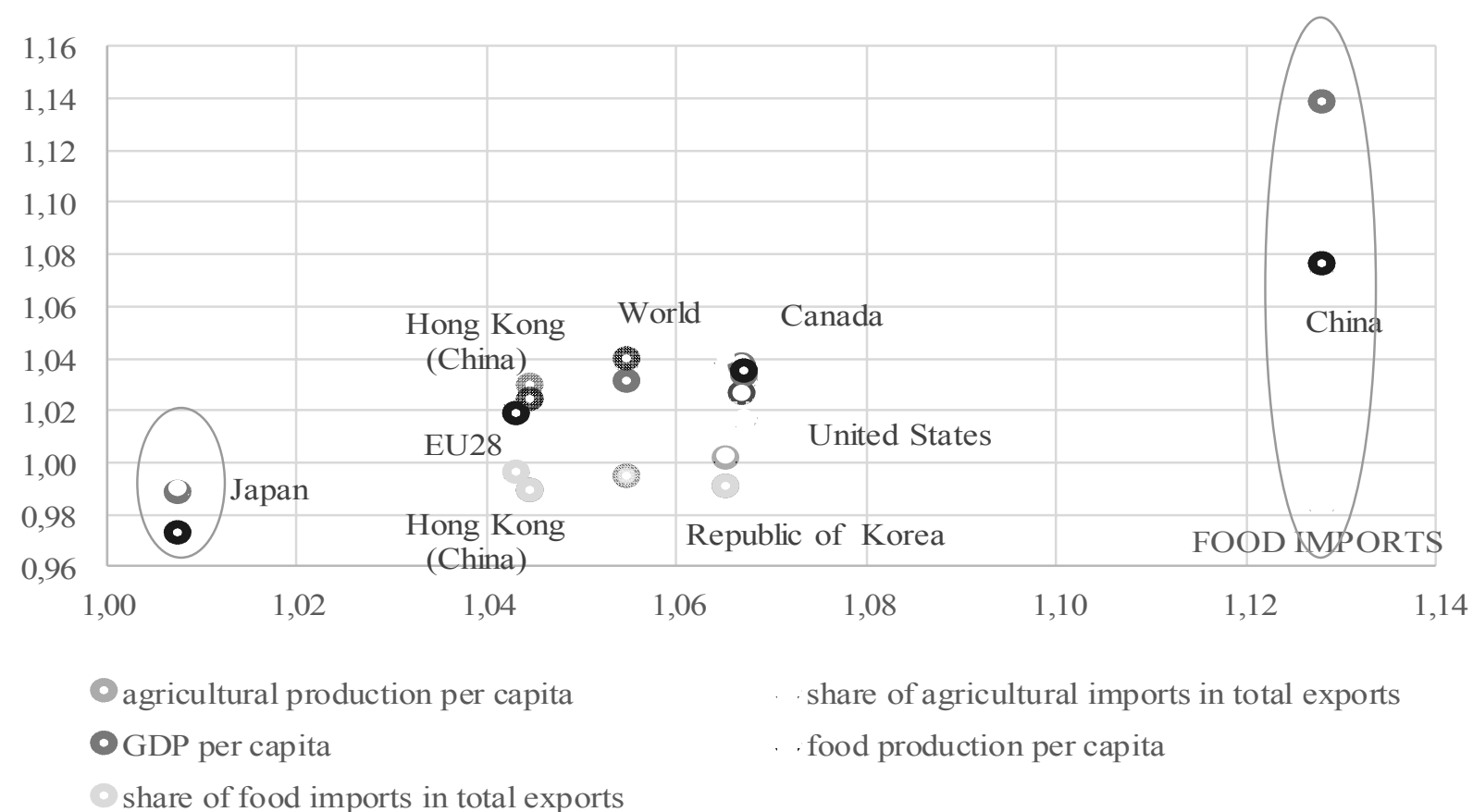

Figure 1. Correlation between changes in the value of food imports and food security levels over the 1995-2015 period

Source: calculations and the author's own study based on: UNCTADstat (2018). International trade in goods and services, Economic trends (1995-2015) and FAOSTAT (2018). Food and agriculture data: Production. Population, Macro-Statistics, Food Security (1995-2015). 
A more complete picture is provided by the analysis of agricultural output per capita. Globally, in 2014, this index reached nearly USD 425, with an annual growth rate of $3.9 \%$. As foodstuff represents a fundamental part of agricultural production, the changes to and the level of food production per capita were only several percent lower. Undeniably, import activities of selected economies depend on their production potential. The higher the intensity of agricultural production and the higher the concentration of agricultural production on a relatively large privately held agricultural area, the weaker the willingness to develop agricultural imports irrespective of global changes. This is especially true for the US, the EU and Canada.

Analysis revealed the evolution of trade activity and food security level of key global market players. To determine the direction of that process and identify the interrelationships, the correlation between changes in the value of agricultural imports and selected food security indices was analysed over the 1995-2015 period. As shown by the results, at a global level, a strong positive correlation exists between agricultural imports and the physical and economic availability of food (except for Japan and Korea where the correlation was moderate), and a weak negative correlation exists between agricultural imports and stability of food security. The increase in agricultural imports was accompanied by a decline in food security levels measured with the total-exportsto-agricultural-imports ratio and the total-exportsto-food-imports ratio. The correlation between these characteristics varied extremely from one country to another.

\section{CONCLUSIONS}

The theoretical and empirical analysis performed in this paper answered the research question asked in the introduction and enabled the implementation of the main research plan which was to assess the openness of food trade in relation to the changing level of food security experienced by main players of the global market. The discussion resulted in the following conclusions and generalizations. In 1995-2015, food imports followed a global growth trend marked by the occurrence of external shocks which slowed down the development of trade flows. Ultimately, food trade volumes nearly tripled while the share of food in total imports decreased, except for Canada, the US and Korea. Note that only the first two of them were not net importers of food.

According to a comparative analysis of food trade and the intensity of the main players' involvement in global food trade, a growth trend was observed, with China and Japan being the main exceptions. The contribution of food products to agricultural GDP varied across countries but was more than ten times higher than trade openness measured by taking into account the profitability of the global economy. The singularities of development of the agri-food sector were also reflected in decreasing values of the exports-to-imports ratio both for agricultural commodities and foodstuff. That ratio doubled in countries other than net importers. Agri-food output per capita followed an upward trend and was driven by local conditions.

According to the analysis of relationships between changes to food imports and selected food security indicators, agricultural imports demonstrate a strong positive correlation with physical and economic availability, and a weak negative correlation with stability. This was true both on a global basis and for different economies covered by this study. Based on the above, a general conclusion may be drawn that economic growth resulted in structural changes which contributed to improving access to food.

\section{REFERENCES}

1. Aksoy, M.A. (2005). The Evolution of Agricultural Trade Flows. In: Aksoy, M.A., Beghin, J.C. (eds.) Global Agricultural Trade and Developing Countries. The International Bank for Reconstruction and Development/The World Bank, Washington, DC.

2. Aurino, E. (2014). Selecting a Core Set of Indicators for Monitoring Global Food Security - a Methodological Proposal. ESS Working Paper 14-06. FAO, Rome. Retrieved from: http://www.fao.org/3/a-i4095e.pdf [Accessed 09.01.2017].

3. Braun, J., Ahmed, A., Asenso-Okyere, K., Fan, S., Gulati, A., Hoddinott, J., Pandya-Lorch, R., Rosegrant, M.W., Ruel, M., Torero, M., van Rheenen, T., von Greb- 
mer, K. (2008). High Food Prices: The What, Who, and How of Proposed Policy Actions. Policy Brief (May 2008). International Food Policy Research Institute, Washington, DC.

4. Brooks, J., Matthews, A. (2015). Trade Dimensions of Food Security. Food, Agriculture and Fisheries Papers 77. OECD Publishing, Paris. DOI: $10.1787 / 5$ js65xn790nv-en

5. Chatterjee, B., Murphy, S. (2014). Trade and Food Security. E15 Initiative. Strengthening the Global Trade System. International Centre for Trade and Sustainable Development and World Economic Forum. Geneva. Retrieved from: https://www.ictsd.org/sites/default/ files/research/E15_Agriculture_Chatterjee_Murphy_ FINAL_0.pdf [14.12.2017].

6. Chen, J., McCarl, B.A., Thayer, A. (2017). Climate Change and Food Security: Threats and Adaptation. In: Schmitz, A., Kennedy, P.L., Schmitz, T.G. (eds.) Frontiers of Economics and Globalization: Food Security in an Uncertain World, 17, pp. 69-84.

7. FAO (2005). The State of Food and Agriculture 2005: Agricultural trade and poverty Can trade work for the poor? Rome: Food and Agriculture Organization of the United Nations. Retrieved from: http://www.fao.org/ docrep/008/a0050e/a0050e00.htm\#TopOfPage [Accessed 09.12.017].

8. FAO (2017). Food Security Statistics. Retrieved from: http://www.fao.org/economic/ess/ess-fs/en/ [Accessed 09.01.017].

9. FAOSTAT (2018). Food and agriculture data: Production. Population, Macro-Statistics, Food Security. 1995-2015. Retrieved from: http://www.fao.org/faostat/en/\#data [Accessed 07.01.017].

10. Herrmann, M. (2009). Food Security and Agricultural Development in Times of High Commodity Prices (UNCTAD/OSG/DP/2009/4). UNCTAD Discussion Papers. Geneva. Retrieved from: http://unctad.org/en/ Docs/osgdp20094_en.pdf [Accessed 21.01.2017].

11. Jaworska, M. (2012). Kontekst globalny zmian w światowym handlu artykułami rolnymi [The global conte$\mathrm{xt}$ of changes in world trade in agricultural products]. Roczniki Naukowe SERiA, 14 (1), pp. 198-202.

12. Krivonos, E., Morrison, J., Canigiani, E. (2015). Trade and Food Security: Links, Processes, and Prospects. In:
Schmitz, A., Kennedy, P.L., Schmitz, T.G. (eds.) Frontiers of Economics and Globalization: Food Security in an Uncertain World, 15, pp. 15-30.

13. Nelson, G.C., Rosegrant, M.W., Palazzo, A., Gray, I., Ingersoll, C., Robertson, R., Tokgoz, S., Zhu, T., Sulser, T.B., Ringler, C., Msangi, S., You L. (2010). Food Security, Farming, and Climate Change to 2050: Scenarios, Results, Policy Options. Food Policy Research Institute, Washington, DC. DOI: 10.2499/9780896291867

14. UNCTAD (2017a). Key Statistics and Trends in International Trade. A Bad Year for World Trade? (UNCTAD/ /DITC/TAB/2016/3). United Nations, Geneva. Retrieved from http://unctad.org/en/PublicationsLibrary/ ditctab2016d3_en.pdf.

15. UNCTAD (2017b). The Role of Science, Technology and Innovation in Ensuring Food Security by 2030 (UNCTAD/DTL/STICT/2017/5). United Nations, Geneva. Retrieved from http://unctad.org/en/PublicationsLibrary/dtlstict2017d5_en.pdf.

16. UNCTADstat (2018). International trade in goods and services, Economic trends. 1995-2015. Retrieved from: http://unctadstat.unctad.org/wds/ReportFolders/reportFolders.aspx [Accessed 04.01.2017].

17. Wacziarg, R., Welch, K. (2008). Trade Liberalisation and Growth: New Evidence. World Bank Economic Review, 22 (2), pp. 187-231. DOI:10.1093/wber/lhn007

18. WTO (2015). International Trade Statistics. Special Focus: World Trade and The WTO: 1995-2014. World Trade Organization, Geneva. Retrieved from: https://www.wto.org/english/res_e/statis_e/its2015_e/ its2015_e.pdf [Accessed 14.07.2017].

19. WTO Statistics Database (2017). The Time Series on international trade: merchandise trade by commodity 1995-2015. Retrieved from: http://stat.wto. org/Home/WSDBHome.aspx?Language=E [Accessed 03.12.0217].

20. Yu, B., You, L. (2013). A typology of food security in developing countries. China Agricultural Economic Review, 5 (1), pp. 118-153, https://doi.org/10.1108/17 561371311294810

21. Zhu, Y. (2016). International trade and food security: conceptual discussion, WTO and the case of China. China Agricultural Economic Review, 8 (3), pp. 399-411. https://doi.org/10.1108/CAER-09-2015-0127 